\title{
Developing German Short Story (Kurzerzählung) during the "COVID-19" Pandemic into a Puppet Show (Puppenspiel) as a Literature Teaching Material in German Department of FBS UNIMED (State University of Medan)
}

\author{
$1^{\text {st }}$ Ahmad Bengar Harahap ${ }^{1}, 2^{\text {nd }}$ Hafniati $^{2}, 3^{\text {rd }}$ Herlina JP Hrp ${ }^{3}, 4^{\text {th }}$ Tiarma Klarita Siallagan $^{4}$ \\ \{ bengar216@gmail.com $\left.{ }^{1}\right\}$
}

Faculty of Language and Art, Universitas Negeri Medan, Jl. Willem Iskandar Pasar V, Medan 1,2,3,4

\begin{abstract}
The study of prose is a part of literary teaching that can be shown on a stage or performance through the drama performance in several ways, one of them is with the German puppet show called Puppenspiel. During the COVID-19 pandemic time, it has a very big impact on all aspects of life, especially on the learning process, including the study of literary works. The government of Indonesia through the Ministry of Education has a policy of limiting activities at the university through the enforcement of online learning systems. Of course, this policy has an impact on the mental and emotional learning of students and as well as lecturers. One of them concerns the process of conducting literary lecture as well as their performances. Short stories in German literature called Kurzerzählung, can be performed through puppet show virtually (online) and offline as a concept of prose studies during the current pandemic. The result can be an interesting anthology of prose to be discussed in research or literary lecture. The aim of this publication is therefore to develop a short German story for a puppet show during the outbreak of the COVID-19 pandemic as literature teaching material in the German Department of FBS UNIMED. This study aims to improve the quality of learning in literature or literature lecture so that students can understand German literature, especially prose science better and more quickly. This study was carried out at the Faculty of Language and Art, German Department UNIMED. The model in this study used the models' Research and Development (R\&D) from Richey and Klein (2007). From the results of the study, German prose anthology books during the outbreak of the COVID-19 pandemic will be created as teaching materials and digital learning media as well as national and international journal articles..
\end{abstract}

Keywords: The Short Story during the Pandemic COVID-19, puppet show.

\section{Introduction}

The prose is one of the most interesting literary works to discuss, not only in terms of elements but also in terms of performance as a prose appreciation. In the study of prose, there is a short story, which is a part of literary works in prose form. Likewise, a short story in German language and literature is called Kurzerzählung. The short story that has been made and interpreted well can be performed in the form of drama, one of them is drama 
performance. In German literature, there are several concepts of drama performance and its appreciation. One of them is in a puppet show or Puppenspiel. The concept of Puppenspiel's performance has similarities and indicators in the competence of learning drama as online and offline.

One of indicator in learning competence for drama and puppet show or Puppenspiel as mentioned above is being able to distinguish drama as a literary work and theater as a performing art, one of them is puppet performances or Puppenspiel.

From the explanation of the indicators regarding puppet show (Puppenspiel) above, it can be concluded that the product or learning outcome of a performance can be enjoyed, lived, and reinterpreted, so it can be a personal experience. The personal experience created is influenced by many aspects or elements. One of them is influenced by aspects or elements of the time when the performance was created. That is called periodization or literary period.

The literary period is a unity of time in the literary development, that is controlled by a certain system of norms or unity of time that has a characteristic and distinctive pronunciation that is different from the previous period. Prose study that has been collected in some literary period becomes a prose anthology of short story anthology at a certain time that experienced by an author.

The COVID-19 pandemic, which is predicted to emerge since the end of 2019, has hit all over the world, including Indonesia. This pandemic is affecting all aspects of life. During the COVID-19 pandemic, the government through the Ministry of Education made a policy limiting activities at the university, so that students and lecturers must carry out the teaching and learning process at home. Technically, universities must implement an online learning system. So even though students and lecturers are at home, they can carry out the teaching and learning process through existing online applications. So that lectures and other academic activities such as research can also be carried out.

In literary lecture, the COVID-19 pandemic has become a periodization of literature that has attracted a lot of people's attention. There are several authors or students, especially those who create short stories as a medium to express their grievances over the perceived impact of this pandemic outbreak. In learning in university, especially in literature or prose lecture, this period has become a topic that can be the theme of teaching materials with several aspects of literary analysis as a whole. This includes the Aktuelle Literatur (Actual Literature) lecture in the German Department of FBS UNIMED.

\section{Theeory}

\subsection{The Definition of Short Story (Kurzerzählung)}

Quoted from the source: https://www.yuksinau.id/cerpen/, there are several terms of the short story as follows:

a. Based on KBBI, the short story is writing about a short tale whose contents do not exceed 10.000 words, which contain about a character.

b. According to Sumardjo and Saini, the short story is a story that does not happen in the real world and it is short.

c. According to Hendy, the short story is not too long writing that contains a single story.

d. According to J.S. Badudu, a short story is an essay that only focuses on one event. 
e. According to Aoh. K.H, the short story is a form of short prose story.

f. According to H. B. Jarsin, the short story is a form of a fairly complete essay consisting of three parts, namely introduction - conflict - conclusion.

Based on the opinion above, it can be concluded that the short story is a short literary work that is fictitious and tells about a problem experienced by the character in a nutshell from the introduction to the end of the problems experienced by the character.

In general, the short story only tells one problem experienced by one character. In addition, the short story only consists of no more than 10.000 words. This is what makes a short story readable in one sitting.

\subsection{The Puppet Show (Puppenspiel) as a part of the Literary Performance}

In the Wikipedia dictionary, it is stated that a puppet show is a person who moves an inanimate object shaped like a human, animal, or mystical creature, or another object to create the illusion that the puppet show becomes "alive". The puppet performer can be visible or hidden from the audience. Puppet performers can move a puppet show indirectly by using sticks, ropes, nets, electronics, or using their own hands which are placed inside the puppet, or holding it on the outside or other parts of the body such as the feet. Some types of puppet shows require two or more puppet performers to work together to create a single puppet show character.

In Indonesia, the beginning of the activity of performing puppet shows as the chosen medium was more as a performing art. The performance can be anywhere even for simple performances that do not require a special place, such as on the terrace, in a market, at a station, or in a field that can reach by children as the audience from the puppet show theater. In Germany, puppet show has another purpose than entertaining but also conveying messages of language or certain issues in a way that is not so serious but entertaining or playing.

This puppet show can use simple items and tools. The hand puppets are sewn from patchwork, then displayed behind a stretched blanket. The audiences are children, teenagers, adults, or the elderly. The aims of puppet show are to accompanying, entertaining, and sharing with the audience.

The themes in the show are similar to dramas in general, such as telling about humanity, society, environment, and history. Story with puppet show becomes more interesting and unique. Currently, puppet shows can also be performed without dialogue as in general puppet shows, but through the body gestures of the puppets, that is driven by a combination of light playing and musical accompaniment that strengthens their performance.

The puppet show is common in big countries and cities. Various cities in Indonesia and various countries such as Germany, Japan, the Netherlands, Australia, the United States, and almost all continents including Asia, Africa, and Europe. So this puppet show is very important to be a learning material in education, language, and literature.

\subsection{COVID-19 Pandemic Time}

According to KBBI, it is interpreted as an epidemic that spreads simultaneously everywhere, covering a wide geographical area. In the most classic sense, it happened when an epidemic spreads to several countries or regions of the world. The disease outbreaks that fall into the pandemic category are diseases that are contagious and have a continuous line of 
infection. So if a case occurs in several countries other than the country of origin, it is still classified as a pandemic.

Looking at the history of the early emergence of COVID-19 according to the source: https://www.voice.com/video/2020/04/03/135739/menilik-re-sejarah-covid-19, it was explained that in early December 2019 some patients with an unknown disease, came to the central hospital of Wuhan, China. Dr. Li Wenliang shared the bad news on social media. The disease that causes pneumonia is thought to be caused by a virus that originated in the Huanan fish market, which also sells wild animals. After entering 2020, the Chinese authorities announced a new type of Coronavirus. Furthermore, the death toll fell into the thousands, and patients outside China were also reported to be increasing. WHO has declared the Corona outbreak (COVID-19) a global pandemic and called on the entire world community to work together to end these difficult times.

Meanwhile, according to data from the COVID-19 cluster formed by the government, the outbreak began in Indonesia around February 2020. Several institutions have also conducted research to predict the peak and end of the COVID-19 pandemic in Indonesia. At least eight institutions estimate that the peak of the pandemic will occur from March to July 2020. Meanwhile, the Director of the Data-Driven Innovation Lab and lecturer at the Singapore University of Technology and Design (SUTD), Professor Jianxi Luo predicts that Indonesia is now at the peak of the COVID-19 pandemic since April 20. His party updated their predictions and estimated that Indonesia would be completely free from the COVID-19 outbreak on October 7, 2020. The end time of the pandemic in each country is different because it depends on the country's adaptation and the government's way of dealing with the pandemic. (Source: Author Yosepha Pusparisa Editor: Aria W. Yudhistira, on: https://katadata.co.id/infografik/2020/05/08/predik-akhir-pandemi-covid-19).

\section{Methods}

This research was conducted by using Research and Development (R\&D) model from Richey and Klein. The development method is descriptive qualitative. This study will develop teaching material for German literature through a short story and its performance during the current phenomenal pandemic outbreak. The data in this study are dialogues, words, sentences, and paragraphs in 32 German short stories written by students in the German Department of FBS UNIMED during the COVID-19 pandemic. The data sources were obtained from books and literature teaching materials themed on actual German proses, short stories and their performances during the COVID-19 pandemic outbreak, hand out, and German literary journal.

The data collection technique used in the early phase of the development model used is to use listening and reading techniques and analyzing the short stories data and interpretation of Puppenspiel's performance is taken using Suyoto's theory in Harahap [1], which consists of general elements: theme and title, message, anthology, value (niveau). Furthermore, the special elements are plot, puppet and character figures (Puppen), setting/background, the figure of speech, language typography, point of view: first-person point of view.

\section{Result and Discussion}


The results of this study have found 32 short stories in German written by 6th-semester students of the German Department of FBS UNIMED Odd semester in the 2020-2021 academic year who are experiencing the COVID19 pandemic.

The results of the analysis of the short stories are as follows:

\subsection{General Elements}

After reading the short stories and watching the puppet shows that have been done, it is possible to analyze the special elements of the short stories and the drama performances in the form of:

a. Theme: The theme contains things about the corona outbreak, pandemic, hopes, and prayers in dealing with this disaster, and there are also ups and downs from the pandemic. There are also themes containing descriptions and concerns or worries, anxiety, and panic, but there is also optimism over the tragedy of the COVID-19 pandemic that has hit both implied and expressed.

b. Title: contains diction around words: Corona, COVID-19, Pandemic, Virus, Social or Physical Distancing, Ausbruch (outbreak), Angst (Fear), Erde (Earth), Leute (Humans or people), Beten und Gott (prayer and God)

c. Mandate: Appeal or positive campaign about the COVID-19 Pandemic

d. Messages have in common in the form of a mandate to:

- Keep personal hygiene,

- Keep the social/physical distance,

- Follow the health protocol

- Obey the government rules,

- Remind ourselves and our family

- Helping others as much as possible

- Keep praying and learning,

- Do not underestimate the virus

- Anthology: educational, religious, and urban literature.

- Niveau (value): these short stories are included in telling stories about people who are wary, complaining, and upset as well as optimistic about what is happening to the world right now, namely the COVID-19 pandemic.

\subsection{Special Elemets}

. The special elements of short stories and performances are:

a. Plot: forward (vorwärts) because it is happening or is still being experienced in the current situation.

b. The characters in the short stories and the puppet shows are dolls and their characters (Puppen), made by themselves or produced together with creativity amid a pandemic atmosphere (joy, sorrow, hope).

c. Setting/background:

Place: performances and short stories are performed at their own homes or residences. But the stories are about the places such as in schools or universities, in supermarkets, in markets, in gardens, and in any locations in Germany. 
Time: anytime, in the morning, midday, afternoon, and evening. Atmosphere: Crowded, lonely, sad, not so happy, and tense.

d. Majas: rhetoric, personification, metaphor, hyperbole.

e. Typography of the language contains dialogue, direct sentences (direkte Rede) and indirect sentences (indirekte Rede), foreign absorption language, and present and future tenses (präsens, perfekt).

f. Point of view: the point of view of the first person (direct actors as directors and actors), because this is a single puppet show

\subsection{Anthology}

Analysis of the short story anthology is an anthology of religious literature, educational literature, and urban literature. In the 32 short stories that are dominant in religious anthologies. The analysis of short stories leads to a religious approach (Islam and Christian). How religion teaches patience in dealing with the outbreak, destiny, and optimism in the greatness of God over the outbreak. Then there is also an anthology of educational literature related to online or distance learning, where learning must go on, and an anthology of urban literature, where writers generally describe how the current situation in the city is. The atmosphere is getting worse by the outbreak of coronavirus that is happening in the city.

From the results above there are several words found in short stories or it can also be called finding, namely changes in words or letters or assimilation of letters from words that come from the language of medical or health or also English. For example, the word Corona as the name of the epidemic virus in German changed to Korona. The letter ' $\mathrm{C}$ ' becomes " $\mathrm{K}$ ". Letter changes are common in German from other languages, especially English.

Then there are absorption words from English into German while there are special words in German. For example, there is the word "pandemic" to Pandemie which is used in short stories. While in German there is its language, namely Ausbruch which means the same thing, outbreak. Then the word symptom and virus that in German is Pest (virus or disease), "mask" in German Maske, and "distance" in German distanz. Furthermore, several analyzes of the short story emphasize optimism and religion, found many words Gott (God), Kampf (Battle, fighting spirit), and Krieg (War) in the sense of fighting the virus. The short stories writers wrote in lowercase the words 'covid', which is an abbreviation of COVID (Corona Virus Disease) as meaning to reduce the 'fear' of the word so that the disease or epidemic can be destroyed.

In the discussion of the anthology, because these German short stories were written by students of the German Department of FBS UNIMED, an anthology of religious literature appears in each analysis. An anthology of religious literature discusses the origin of disease and beliefs or requests to God for refuge from disease and hopes that it can be destroyed quickly or can be treated. Then an anthology of urban literature appears in the analysis of short stories with the reason that the background of this epidemic is viral in cities, countries, and the world. The words 'China' also appear, Stadt (city), Land oder Staat (Country), Erde (earth), Welt (world), International und National (International and national).

From the short stories that have been written, students design puppet shows (Puppenspiel) which are presented in a video. These puppet shows are carried out by students themselves, such as making or selecting puppet characters, making properties, determining the intonation of each character, and also recording videos.

Students are encouraged to use objects around them, such as dolls. Some students choose to produce their puppets, such as drawing characters and cutting them according to patterns, 
sewing with flannel, and designing socks so that they look like dolls. Some students add properties to complement their puppet shows, such as making chairs and tables out of cardboard.

To clarify the background of the story, such as the setting of place and time, some students make a background such as a picture of a garden, school, or house. Backgrounds are made with paper, and some use virtual backgrounds (as is often used in video conferencing/Zoom). While the background of the atmosphere is described with music and speech intonation. Because there are several characters in a short story (1 to 5 characters), students make different intonations for each character.

The puppet show is done simply in their homes. However, the students tried to make it look like a real puppet show. Students make a stage using cardboard or cloth for their puppet show, which is decorated in such a way as to be attractive.

This puppet show is very useful. In addition to fulfilling the Aktuelle Literatur lecture, this puppet show succeeded in inviting students to be creative even though they had limited tools and materials. Students are also able to follow current trends in different ways, such as in this COVID-19 pandemic situation. They understand well the current situation so that they are not only trapped but can make positive campaigns, such as an appeal to comply with health protocols.

The pandemic period has affected the mentality of lecturers and students. By making German literature lecture interesting like this, students can reduce the stress because online learning and increase their immunity.

\section{Conclusion}

From the results of the research described above, the conclusions are as follows:

a. In the research process of the Research and Development (R\&D) model or Richey and Klein's design and development research, it can be concluded as follows:

- Planning, at this phase 32 short stories are collected as data and first analyzed the general elements and special elements of the short stories using Suyoto's theory in Harahap [1] which consists of General Elements of Theme and Title, Message, Anthology, Niveau (value). Furthermore, the Special Elements are Plot, puppet and character figures (Puppen), setting/background, the figure of speech, language typography, point of view: first-person. And then analysis of literary anthologies in short stories, 1) Anthology of Religious Literature, 2) Anthology of Urban Literature, and 3) Anthology of Educational literature.

- Development, in this development phase, the short stories analysis that has been carried out is designed to be a puppet show with the provisions according to the contents of the short story, namely a) Characters and characterizations/characteristics of characters, b) Themes and messages, c) Setting, d) Plot, e) Point of view/style of storytelling. Then the short stories are collected into an anthology of short stories as literature teaching materials with the following criteria: 1) Categories of books as teaching materials, 2) Content descriptions, 3) Components of Teaching Materials. Then this criterion is further developed with components, namely: 1) The front section, such as: outer cover, inner cover, foreword, preface, table of 
contents. 2) The content section, such as: title, learning objectives, concept map, material, summary, practice questions, evaluation of learning outcomes, 3) The closing section, such as: bibliography, glossary, and explanation of paper size, font, and typeface.

- Evaluation, to be able to use teaching materials in the "Aktuelle Literatur" lecture, the feasibility and appropriateness of the outcomes are evaluated involving linguists on German native speakers and practitioners or literary activists (short stories) at TBSU.

b. The results of this study are a collection of digital media for German puppet shows and German short stories anthology books during the COVID-19 pandemic as teaching materials for literature to be used in literature lectures (Literatur) in the German Department of FBS UNIMED in particular and in other universities in general.

\section{References}

[1] Harahap AB. Antologi Puisi Jerman di Masa Wabah Pandemi Covid19. Unimed Press, Medan; 2020. 